\title{
PELATIHAN PENYUSUNAN RENCANA KERJA MADRASAH (RKM) UNTUK PENINGKATAN AKREDITASI DI MTS NW BEBUAK DESA BEBUAK KECAMATAN KOPANG KABUPATEN LOMBOK TENGAH
}

\author{
Jumrah \\ Institut Agama Islam Negeri Mataram \\ E-mail: ghaisan2014@gmail.com
}

\begin{abstract}
Abstrak: Pelatihan penyusunan Rencana Kerja Madrasah (RKM) di MTS NW Bebuak bertujuan untuk meningkatkan akreditasi MTS NW Bebuak kecamatan Kopang. Pihakpihak yang dilibatkan dalam kegiatan ini adalah ketua atau perwakilan yayasan, kepala sekolah beserta Seluruh jajarannya, perwakilan wali murid atau komite madrasah, tim pengabdi IAIN Mataram serta Narasumber yang Expert di bidangnya. Pendekatan yang digunakan dalam kegiatan ini yaitu pelatihan yang dilakukan dalam dua kali pertemuan yang melibatkan kepala madrasah, seluruh guru, perwakilan komite madrasah, serta ketua atau perwakilan yayasan. Sumber Daya Manusia yaitu Pengabdi sendiri selaku penanggungjawab kegiatan, Pemateri yang expert di bidangnya, Ketua Yayasan, Kepala Sekolah dan segenap jajarannya serta Perwakilan wali siswa selaku obyek kegiatan. Mahasiswa KKP IAIN Mataram sebagai bagian dari Tim pelaksana kegiatan yang membantu Pengabdi dalam mempersiapkan dan melaksanakan kegiatan. Adapun instrument pengabdian yang digunakan, antara lain: 1). Deep Interwiew atau wawancara mendalam. 2). Observasi. 3). Dokumentasi. Hasil kegiatan ini yaitu tersusunya Rencana Kerja Madrasah (RKM) NW Bebuak yang disusun oleh tim penyusun dokumen akreditasi yang merupakan peserta aktif dari kegiatan pelatihan ini yaitu kepala madrasah dan guru-guru, serta mempertimbangkan pula masukan dari komite sekolah serta pihak yayasan itu sendiri.
\end{abstract}

Kata Kunci: Rencana Kerja Madrasah (RKM), Akreditasi.

\section{PENDAHULUAN}

Akreditasi sekolah/madrasah adalah proses penilaian secara komprehensif terhadap kelayakan dan kinerja satuan dan/atau program pendidikan, yang dilakukan sebagai bentuk akuntabilitas publik. Di dalam proses akreditasi, sebuah sekolah/madrasah dievaluasi dalam kaitannya dengan arah dan tujuannya, serta didasarkan kepada keseluruhan kondisi sekolah/madrasah sebagai sebuah institusi belajar. Walaupun beragam perbedaan dimungkinkan terjadi antar sekolah/madrasah, tetapi sekolah/madrasah dievaluasi berdasarkan standar tertentu. Standar tersebut diharapkan dapat mendorong dan menciptakan suasana kondusif bagi pertumbuhan pendidikan dan memberikan arahan untuk evaluasi diri yang berkelanjutan, serta menyediakan perangsang untuk terus berusaha mencapai mutu yang diharapkan. Dalam proses akreditasi, terdapat 8 (delapan) standar penilaian, yaitu Standar Isi, Standar Proses, Standar Kompetensi Lulusan, 
Transformasi, Vol. 12, No. 1, Januari 2016: 81-91

Standar Pendidik dan Tenaga Kependidikan, Standar Sarana dan Prasarana, Standar Pengelolaan, Standar Pembiayaan dan Standar Penilaian.

Terkait akreditasi, MTs NW Bebuak telah diakreditasi oleh Badan Akreditasi Nasional Sekolah/Madrasah pada tanggal 31 Desember 2012, di mana pada saat itu, MTs NW Bebuak mendapatkan akreditasi B yang berlaku sampai tahun ajaran 2017/2018. Berdasarkan hasil wawancara dengan Kepala Madrasah, diketahui bahwa Madrasah setidaknya memiliki kelemahan sebanyak 3 (tiga) standar dari 8 (delapan) standar komponen penilaian akreditasi. Ketiga standar tersebut yaitu standar kompetensi lulusan, standar sarana dan prasarana, serta standar pengelolaan ${ }^{72}$. Berdasarkan hasil observasi peneliti, standar pengelolaan merupakan standar yang dapat diperbaiki dan dipersiapkan dengan lebih baik oleh pihak Madrasah dalam waktu yang singkat dibandingkan dengan kedua standar lainnya dalam mempersiapkan akreditasi tahun 2017.

Salah satu standar pengelolaan yang belum dimiliki MTs NW Bebuak yaitu Dokumen Rencana Kerja Madrasah (RKM). Rencana Kerja Madrasah (RKM) merupakan sebuah proses perencanaan atas semua hal dengan baik dan teliti untuk mencapai tujuan pendidikan. Penyusunan RKM dapat disesuaikan dengan kekhasan, kondisi dan potensi daerah, sosial budaya masyarakat, potensi sekolah dan kebutuhan peserta didik. RKM disusun sebagai pedoman kerja pengembangan sekolah, dan sebagai bahan acuan untuk mengidentifikasi serta mengajukan sumber daya yang diperlukan.

Berdasarkan uraian di atas, maka kegiatan Pengabdian ini difokuskan pada pemberian pelatihan terkait penyusunan Rencana Kerja Madrasah (RKM). Rencana Kerja Madrasah ini dimaksudkan agar dapat dipergunakan sebagai kerangka acuan oleh Kepala Madrasah dalam mengambil kebijakan, disamping itu sebagai pedoman dalam mencapai keberhasilan pelaksanaan progam belajar mengajar dan administrasi Madrasah yang lain, agar pengelola Madrasah tidak menyimpang dari prinsip-prinsip manajemen.

Alasan utama mengapa MTS NW Bebuak dijadikan sebagai object pengabdian masyarakat adalah karena MTS NW Bebuak merupakan satu-satunya MTs yang ada di Desa Bebuak Kecamatan Kopang Kabupaten Lombok Tengah Propinsi NTB. Walaupun demikian, MTs ini memiliki kompetitor yaitu SMP Islam

\footnotetext{
${ }^{72}$ Hasil Wawancara dengan Kepala MTs NW Bebuak, 23 Juni 2016
} 
Swasta yang terletak pada desa yang sama dan beberapa Sekolah Menengah Pertama lainnya yang berada di sekitar Desa Bebuak. Kondisi ini merupakan potensi ancaman yang nyata bagi MTs NW Bebuak untuk terus berbenah dalam meningkatkan kualitas pendidikan sehingga memiliki daya saing dalam berkompetisi dengan sekolah lainnya.

Akreditasi sekolah/madrasah merupakan salah satu barometer kualitas pendidikan. Sekolah/Madrasah dengan akreditasi A tentunya akan lebih dipilih masyarakat dibandingkan dengan Sekolah/Madrasah berakreditasi B. Pada tahun 2017 yang akan datang, MTs NW Bebuak akan diakreditasi oleh Badan Akrediatasi Nasional Sekolah/Madrasah di mana pada akreditasi terakhir (tahun 2012), MTs NW Bebuak mendapatkan akreditasi B. Hal inilah yang menjadi fokus pengabdian, dimana tersusunya dokumen Rencana Kerja Madrasah (RKM) yang lengkap dan berkualitas diharapkan mampu meningkatkan nilai akreditasi dari B menjadi A.

Untuk mencapai kondisi ideal yang diuraikan di atas, tentunya membutuhkan strategi-strategi yang bisa diterapkan strategi yang diterapkan tersebut terdiri dari beberapa tahapan yaitu (1) tahapan mapping existing (pemetaan terkini) kondisi Madrasah, (2) review hasil penilaian akreditasi periode sebelumnya, (3) pelatihan menyusun Rencana Kerja Madrasah (RKM) serta (4) monitoring dan evaluasi. Model pelaksanaan pengabdian ini dilakukan dalam desain pelatihan menggunakan metode ceramah dan diskusi.

Khusus untuk perumusan dokumen RKM, dilakukan melalui 4 (empat) tahap, yaitu: (1) identifikasi tantangan, (2) analisis pemecahan tantangan, (3) penyusunan program, (4) penyusunan rencana biaya dan pendanaan. Pihak-pihak yang terlibat dalam pengabdian ini adalah: 1). Ketua dan atau Perwakilan Ketua Yayasan; 2). Kepala Sekolah Beserta Seluruh Jajarannya; 3). Perwakilan Wali Murid dan atau Komite Madrasah; 4). Tim pengabdi dari IAIN Mataram; 5). Narasumber yang Expert di bidangnya.

Dalam melakukan kegiatan pengabdian ini, sumberdaya atau resources yang dimiliki antara lain: 1). Dana Pengabdian yang berasal dari DIPA IAIN Mataram Tahun 2016. Dana ini digunakan untuk menyediakan konsumsi peserta dan pemateri, ATK peserta, uang transport peserta, dan hal-hal lain yang membutuhkan pendanaan. 2). Sumber Daya Manusia. Sumber daya manusia (SDM) yang dimaksud dalam kegiatan pengabdian ini yaitu: a. Pengabdi sendiri 
selaku penanggungjawab kegiatan; b. Pemateri yang expert di bidangnya; c. Ketua Yayasan, Kepala Sekolah dan segenap jajarannya serta Perwakilan wali siswa selaku obyek kegiatan; d. Mahasiswa KKP IAIN Mataram sebagai bagian dari Tim pelaksana kegiatan yang membantu Pengabdi dalam mempersiapkan dan melaksanakan kegiatan.

Instrument pengadian merupakan sarana atau alat yang digunakan Pengabdi dalam melaksanakan kegiatan. Adapun instrument pengabdian yang digunakan, antara lain: 1). Deep Interwiew atau wawancara mendalam, 2). Observasi, 3). Dokumentasi.

\section{PEMBAHASAN}

Pelaksanaan program Madrasah binaan dimulai dengan kegiatan awal berupa koordinasi dengan pihak terkait dalam rangka mensukseskan kegiatan madrasah binaan. Koordinasi pertama dilakukan dengan Ketua Yayasan. Melalui Ketua Yayasan, kami diperkenalkan dengan Kepala Sekolah sebagai penanggung jawab teknis pelaksanaan kegiatan belajar mengajar di Madrasah. Pada pertemuan awal dengan kepala sekolah, dilakukan wawancara tentang profil sekolah, pada kesempatan itu pula pengabdi bertanya tentang hal yang paling dibutuhkan oleh madrasah saat ini apa untuk perbaikan kualitas madrasah, kepala madrasah saat itu menguraikan banyak hal dan yang paling berkesan adalah ketika kepala madrasah menjelaskan bahwa madrasah mereka sudah diakreditasi untuk pertama kalinya dengan nilai B serta akan melakukan akreditasi kembali pada tahun 2017. Hal ini cukup menarik perhatian pengabdi, pengabdi mengusulkan kegiatan pelatihan penyusunan RKM sebagai salah satu langkah persiapan untuk akreditasi selanjutnya. Kegiatan ini diusulkan berdasarkan kelemahan yang ada pada akreditasi sebelumnya, dimana ketidakadaan RKM ini menjadi salahsatu penyebab rendahnya nilai akreditasi madrasah. Kepala Madrasah merespon dengan sangat baik rencana kegiatan Madrasah Binaan tersebut, bahkan Beliau langsung memanggil Wakil Kepala Sekolah dan beberapa Guru untuk mensinkronkan rencana kegiatan secara lebih mendetail. Setelah dilakukan komunikasi awal tersebut, akhirnya disepakati jumlah calon peserta dan jadwal kegiatan sehingga tidak mengganggu proses belajar mengajar siswa. Seluruh calon peserta yang telah diidentifikasi, dilakukan konfirmasi balik untuk 
memastikan kesediaannya dalam mengikuti kegiatan Madrasah Binaan. Setelah beberapa hari, akhirnya Kepala Sekolah melakukan konfirmasi balik tentang kesediaan calon peserta yang kemudian diputuskan bahwa calon peserta yang diidentifikasi tersebut semuanya mau mengikuti kegiatan tersebut, dimana jumlah peserta semuanya adalah 30 (tiga puluh) orang.

Kegiatan pelatihan penyusunan rencana kerja madrasah (RKM) untuk peningkatan akreditasi ini berlangsung selama dua kali pertemuan yaitu pada tanggal 24 dan 25 September 2016. Kegiatan ini dilakukan di Aula MTS NW Bebuak Kecamatan Kopang. Kegiatan diawali dengan registrasi peserta yang dipandu oleh tim pengabdian masyarakat IAIN Mataram, kemudian dilanjutkan dengan acara pembukaan.

Acara pembukaan pelatihan penyusunan rencana kerja madrasah (RKM) untuk peningkatan akreditasi ini dihadiri oleh ketua yayasan, kepala madrasah, perwakilan komite madrasah, serta semua guru - guru yang juga menjadi peserta pelatihan. Mengawali pembukaan, pengabdi melaporkan segala sesuatu yang terkait dengan rencana kegiatan mulai dari latar belakang pengabdian, tujuan dan sasaran serta teknis pelaksanaan kegiatan. Pengabdi menyampaikan ucapan terima kasih kepada Ketua Yayasan serta Kepala Madrasah yang telah mendukung diadakannya kegiatan pelatihan ini. Ucapan terima kasih pula disampaikan kepada perwakilan komite madrasah serta semua guru-guru yang berkenan hadir sebagai peserta pelatihan. Lebih jauh, beliau juga menjelaskan sedikit tentang goals pelaksanaan pelatihan dan mengharapkan semua peserta pelatihan dapat mengikuti kegiatan ini dengan bersungguh-sungguh. Mengingat pentingnya pelatihan ini, kembali diminta kepada peserta untuk antusias serta menjadi peserta yang aktif.

Acara dilanjutkan dengan sambutan Ketua Yayasan. Ketua Yayasan dalam sambutannya menyampaikan ucapan terima kasih atas dipilihnya MTS NW Bebuak sebagai lokasi Pengabdian Masyarakat IAIN Mataram serta beliaupun menyampaikan permohonan maaf bila ada kekurangan selama kegiatan ini berlangsung. Sambutan berikutnya disampaikan oleh Kepala Madrasah yang sekaligus membuka kegiatan. 
Transformasi, Vol. 12, No. 1, Januari 2016: 81-91

\section{Penyampaian Materi Oleh Narasumber}

Materi yang disampaikan oleh Dr. Nurrahmah, M.Pd berjudul "Penyusunan Rencana Kerja Madrasah (RKM)". Pada awal pemaparannya, narasumber menyampaikan atau memperkenalkan diri, kemudian meminta semua peserta untuk memperkenalkan diri juga. Hal ini dilakukan agar narasumber dan peserta dapat saling mengenal satu sama lain sekaligus untuk mencairkan suasana kelas. Setelah itu, pemateri membuka pelatihan dengan bertanya kepada peserta tentang akreditasi dan rencana kerja madrasah yang mereka pahami. Ada beberapa peserta yang menjawab sesuai dengan pengetahuan mereka. Setelah itu pemateri mulai menjelaskan materi pelatihan dengan menggunakan powerpoint. Ringkasan materi yang disampaikan oleh pemateri adalah sebagai berikut:

\section{Latar Belakang Perlunya RKM}

1. Di lingkungan sekolah/madrasah, perencanaan sebagai salah satu komponen yang berfungsi sebagai pengendali manajemen memegang peran penting dalam upaya kemajuan sekolah. Rencana diibaratkan suatu peta.

2. Mengingat betapa pentingnya sebuah perencanaan bagi sekolah/madrasah, setiap sekolah/ madrasah membutuhkan perencanaan yang terprogram dan terarah. Perencanaan meliputi rencana jangka menengah dan pendek

Perumusan RKM merupakan suatu hal yang sangat penting karena perumusan RKM merupakan suatu hal yang sangat penting, karena RKM dapat digunakan sebagai:

1. Pedoman kerja (kerangka acuan) dalam mengembangkan Madrasah

2. Dasar untuk melakukan monitoring dan evaluasi pelaksanaan pengembangan Madrasah

3. Sebagai bahan acuan untuk mengidentifikasi dan mengajukan sumberdaya pendidikan yang diperlukan dalam pengembangan Madrasah.

4. Tujuan utama perumusan RKM adalah untuk dapat mengetahui secara rinci tindakan-tindakan yang harus dilakukan sehingga tujuan, kewajiban, dan 
sasaran pengembangan Madrasah dapat dicapai, dan dapat dipertanggung jawabkan.

5. Memperhitungkan harapan-harapan pemangku kepentingan dan kondisi nyata Madrasah

\section{Landasan Hukum}

1. UU No. 20 Tahun 2003 Tentang Sistem Pendidikan Nasional dalam Pasal 8 dan 48

2. PP No. 19 Tahun 2005 Tentang Stándar Nasional Pendidikandalam Pasal 49 dan 53

3. Permendiknas No. 19 Tahun 2007 Tentang Stándar Pengelolaan Pendidikan dalam Angka 4 poin 1 dan 2

4. Kepmendiknas 129 Tahun 2004 Tentang Standar Pelayanan Manimal Bidang Pendidikan dalam 3.1

5. Undang-Undang Nomor 25 Tahun 2004 tentang Sistem Perencanaan Pembangunan Nasional,

6. Undang-Undang Nomor 20 Tahun 2003 tentang Sistem Pendidikan Nasional,

7. Peraturan Pemerintah Nomor 19 Tahun 2005 tentang Standar Nasional Pendidikan,

8. Permendiknas No. 19 Tahun 2007 tentang Standar Pengelolaan Pendidikan

9. Permendagri No. 59 Tahun 2007 tentang Pedoman Pengelolaan Keuangan Daerah serta Rencana Strategis Departemen Pendidikan Nasional 2005 - 2009. Ciri-Ciri Rencana Kerja Madrasah (RKM) yang baik

1. Terintegrasi, yakni mencakup perencanaan keseluruhan program yang akan dilaksanakan oleh Madrasah/madrasah;

2. Multi-tahun, yaitu mencakup periode empat tahun;

3. Dimutakhirkan, artinya setiap tahun terus diperbaharui sesuai dengan perkembangan terakhir;

4. Multi-sumber, yaitu mengindikasikan jumlah dan sumber dana masing-msing program. Masalnya daribantuan orang tua murid, APBD Kabupaten/Kota, APBD Propinsi APBN dan sumbangan dari Masyarakat atau sumber lainnya; 
Transformasi, Vol. 12, No. 1, Januari 2016: 81-91

5. Disusun secara partisipatifoleh kepala Madrasah, Komite Madrasah dan dewan pendidik dengan melibatkan pemangku kepentingan lainnya;

6. Pelaksanaannya dimonitor oleh Komite Madrasah dan pemangku kepentingan yang lainnya.

\section{Alur penyusunan RKM}

1. Persiapan, Sebelum perumusan RKM dilakukan, Kepala Madrasah \& Guru bersama Komite Madrasah membentuk Tim Perumus RKM yang disebut Kelompok Kerja Rencana Kerja Madrasah. KKRKM beranggotakan 6 orang yang terdiri dari unsur : kepala madrasah, wakil kepala madrasah, guru, wakil dari TU, dan wakil dari komite madrasah.

2. Perumusan RKM dilakukan melalui 4 tahap, yaitu (1) identifikasi tantangan, (2) analisis pemecahan tantangan, (3) penyusunan program, (4) penyusunan rencana biaya dan pendanaan.

Acara penutupan berlangsung pada tanggal 25 september 2016. Penutupan dilakukan oleh kepala MTS NW Bebuak Kecamatan Kopang. Dalam sambutannya, bapak Kepala Madrasah mengucapkan terima kasih kepada IAIN Mataram yang telah bersedia melakukan pengabdian masyarakat di MTS NW Bebuak Kecamatan Kopang. Semoga program ini akan terus berlanjut di masa yang akan datang.

Kepala Madrasah sangat senang melihat antusiasme semua guru peserta pelatihan karena selama kegiatan berlangsung, bapak kepala Madrasah juga menjadi peserta aktif dalam kegiatan pelatihan ini. Selain itu, Kepala Madrasah juga mengajak kepada seluruh peserta untuk menindaklanjuti semua tugas yang diberikan oleh tim pengabdian masyarakat IAIN Mataram dengan sama-sama menyusun Rencana Kerja Madrasah (RKM) sebagai langkah persiapan untuk menghadapi proses akreditasi pada tahun 2017 mendatang.

Sebagai akhir dari penyampaian sambutannya, bapak Kepala Madrasah mengajak semua peserta dan hadirin untuk mengucapkan "alhamdulillah" sebagai tanda berakhirnya atau ditutupnya acara pelatihan penyusunan Rencana Kerja Madrasah (RKM) di MTS NW Bebuak Kecamatan Kopang Kabupaten Lombok Tengah. 
Setelah berakhirnya kegiatan pelatihan, tidak berarti berakhir pula kegitaan pengabdian kepada masyarakat ini, namun masih ada rangkaian kegiatan berikutnya yaitu monitoring dan evaluasi atau kegiatan pendampingan pasca pelatihan. Pendampingan ini dilakukan sebanyak tiga kali, yakni tanggal 04 Oktober 2016, 21 Oktober 2016, dan 01 November 2016. Kegiatan ini dilakukan dengan cara tim pengabdian masyarakat IAIN Mataram (Jumrah, M.Pd serta melibatkan mahasiswa KKP) berkoordinasi dengan kepala sekolah dan guru-guru peserta pelatihan yang juga menjadi tim penyusun dokumen akreditasi. Dengan bekal ilmu dan materi yang didapatkan oleh peserta pada kegiatan pelatihan, tim pengabdi, kepala madrasah, serta guru-guru peserta pelatihan melakukan refreshment terkait langkah-langkah penyususnan Rencana Kerja Madrasah (RKM). Setelah diadakan refreshment, tim pengabdi kemudian membimbing kepala madrasah serta guru-guru untuk mulai menyusun RKM, selain itu juga ditentukan waktu kunjunngan berikutnya untuk melihat perkembangan produk RKM yang disusun oleh pihak madrasah sehingga tujuan akhir dari kegiatan pelatihan ini dapat tercapai yaitu adanya produk berupa Rencana Kerja Madrasah (RKM) dari MTS NW Bebuak yang akan digunakan sebagai dokumen pelengkap pada kegiatan akreditasi tahun 2017 nanti.

\section{PENUTUP}

Kegiatan Pengabdian Masyarakat ini sangat bermanfaat bagi peningkatan nilai akreditasi MTS NW Bebuak Kecamatan Kopang karena berdasarkan analisis dan kajian tentang kekurangan pada dokumen akreditasi MTS NW Bebuak, ditemukan bahwa salah satu kekurangan yang membuat nilai akreditasi madrasah tidak maksimal adalah tidak adanya dokumen Rencana Kerja Madrasah (RKM). Pelatihan penyusunan RKM dirasakan sangat tepat oleh semua peserta dalam hal ini semua guru, perwakilan komite, ketua yayasan, terutama kepala madrasah yang menjadi ketua panitia penyusunan dokumen akreditasi karena bisa mereka jadikan pedoman dalam menyusun RKM sebagai dokumen pelengkap dalam kegiatan akreditasi yang akan dilakukan pada tahun 2017 mendatang. Mengingat 
Transformasi, Vol. 12, No. 1, Januari 2016: 81-91

pentingnya pelatihan ini, semua peserta sangat antusias mengikuti kegiatan pelatihan ini dan sangat menikmati penjelasan dari narasumber sampai akhir

Pelatihan penyusunan Rencana Kerja Madrasah (RKM) sangat sesuai dengan kebutuhan MTS NW Bebuak Kecamatan Kopang karena sebelum dilakukan kegitan dilakukan observasi awal tentang apa yang sebenarnya dibutuhkan oleh madrasah. Oleh karenanya, diharapkan agar setiap kegiatan pengabdian yang dilakukan hendaknya Tim pengabdian melakukan observasi langsung ke lapangan untuk melihat kondisi real lapangan serta kebutuhannya apa. Sehingga kegiatan pengabdian yang dilakukan bisa benar-benar dirasakan manfaatnya oleh madrasah yang dijadikan target kegiatan. Selain itu, hal yang harus dperhatikan pula adalah pendampingan yang dilakukan pasca kegiatan. Bagian ini adalah bagian yang sangat penting karena merupakan realisasi dari kegiatan pelatihan yang dilakukan serta tahap inilah yang bisa menjamin adanya produk dari kegiatan pengabdian ini atau tidak. Jadi, kegiatan pendampingan sama pentingnya dengan kegiatan pelatihan itu sendiri. Selain itu, peningkatan anggaran pengabdian kepada masyarakat kiranya perlu ditingkatkan mengingat banyaknya madrasah yang membutuhkan materi penting tersebut.

\section{DAFTAR PUSTAKA}

Arikunto, S., Prosedur Penelitian Suatu Pendekatan Praktik, Penerbit Jakarta: Rineka Cipta, 2005.

Creswell, J.W., Penelitian Kualitatif \& Desain Riset: Memilih Diantara Lima Pendekatan, Edisi-3. Yogyakarta: Penerbit Pustaka Pelajar, 2004

Departemen Pendidikan Nasional, Manajemen Peningkatan Mutu Berbasis Sekolah. Buku 4. Jakarta: DEPDIKNAS, Direktorat Jenderal Pendidikan Dasar dan Menengah, Direktorat Sekolah Lanjutan Tingkat Pertama, 2001

Keputusan Menteri Pendidikan Nasional Republik Indonesia Nomor 87, Tentang Akreditasi Sekolah, 2002

Maleong, L.J., Metode Penelitian Kualitatif, Bandung: Remaja Rosdakarya, 2009. 
Jumrah, Pelatihan Penyusunan Rencana...

Muhaimin, dkk., Manajemen Pendidikan: Aplikasinya Dalam Penyusunan Rencana Pengembangan Sekolah/ Madrasah, Jakarta: Kencana, 2009.

Muhroji, dkk., Manajemen Pendidikan : Pedoman bagi Kepala Sekolah Dan Guru. Surakarta : University Muhammadiyah Press, 2009.

Mulyasa, E., Manajemen Berbasis Sekolah, Bandung. Remaja Rosdakarya, 2002.

Mustofa, Akreditasi Sekolah/Madrasah". http://mustofamuz. blogspot.com, Diakses pada tanggal 10 Oktober 2011.

Nanang, F., Landasan Manajemen Pendidikan . Bandung: Remaja Rosdakarya, 2004.

Patilima, H., Metode Penelitian Kualitatif, Malang: UMM Press,2010

Permendiknas Nomor 22 Tentang Standar Proses Pendidikan Dasar dan Menengah, 2006.

Permendiknas Nomor 69 Tentang Standar Biaya Non Operasional, 2009.

Sugiyono, Metode Penelitian Kuantitatif, Kualitatif dan R\&D, Bandung: Penerbit Alfabeta., 2014.

Sumaryanto, Kajian Penyelenggaraan Akreditasi Sekolah Pada Pendidikan Dasar, Jakarta: Rineka Cipta, 2008.

Suryosubroto, B., Manajemen Pendidikan di Sekolah, Jakarta: Rineka Cipta, 2004. 